$\xi=$ 不

\title{
Density distribution functions of faults and scaling relations
}

\author{
Michele Caputo $^{1,2}$, Riccardo Caputo ${ }^{3,4 *}$ \\ ${ }^{1}$ Dipartimento di Fisica, Università La Sapienza, Roma, Italy \\ ${ }^{2}$ Texas A\&M University, College Station, Texas \\ ${ }^{3}$ Dept. Physics and Earth Sciences, Ferrara University, Ferrara, Italy \\ ${ }^{4}$ Research and Teaching Center for Earthquake Geology, Tyrnavos, Greece \\ *Corresponding author E-mail: rcaputo@unife.it
}

\begin{abstract}
In the present note, we analyse various seismological datasets collected in different geological and tectonic settings as well as at different time and space scales, like seismic sequences, regional background seismicity, aftershock sequences, microseismic data, and swarms and induced seismicity. We investigate these datasets in terms of statistical distribution of single parameters focusing on stress drop $(\Delta \sigma)$, scalar seismic moment $\left(\mathrm{M}_{0}\right)$ and fault's dimension (often referred to as faults' radius, $\mathrm{r}_{0}$ ). In particular, we systematically obtain the density distribution functions (ddfs) of each parameter verifying the possible extension of the regression curves. We also analyse the correlations between the investigated parameters by comparing the slopes of the ddf for each dataset. Another goal of this investigation is to verify a possible similarity between comparable and different datasets (i.e. collected in similar or different geological and tectonic settings and range of magnitudes), to verify the stability of the ddf when using different methods as well as the variability of the stress drop even in the same seismological region. We suggest that even more accurate data covering wider ranges of values would be desirable in order to be of practical use like seismotectonic characterization, ground motion prediction and seismic hazard analyses, while the representation of the seismicity for any seismogenic region should be not limited to the $b$ (or $b_{0}$ ) value of the Gutenberg-Richter curve.
\end{abstract}

Keywords: Seismic Parameters; Statistical Analysis; Stress Drop.

\section{Introduction}

The problem of developping stochastic models for the analysis of catalogues of regional earthquakes has raised strong interest since the definition of important earthquake parameters such as fault scalar moment tensor $\left(\mathrm{M}_{0}\right)$, faults' dimension (often referred to as source radius, $\mathrm{r}_{0}$, by assuming a circular fault) and stress drop $(\Delta \sigma)$ (Brune 1968, Aki 1972, Hanks and Wyss 1972, Kanamori and Anderson 1975, Madariaga 1976). The analysis of the catalogues including these parameters has given confidence on the validity and meaning of these parameters however settling some questions such as that i) concerning the constant stress drop (Hanks 1977, Abercrombie 1995, Caputo 1998, Ide and Beroza 2001, Ide et al. 2003, Kanamori and Rivera 2004, Shearer et al. 2006, Allmann and Shearer 2009, Oth 2010, Senatorsky 2012, Somei et al. 2014, Hauksson 2015), ii) its use for predicting the ground motion and hence for better assessing the seismic hazard (Caputo 1981, Boore 1983, Asano and Iwata 2011, Baltay et al. 2013, Cotton et al. 2013, Oth and Kaiser 2014), iii) the estimate of the stress in the Earth crust and fault zones (Knopoff 1958, McGarr 1999, Bilek et al. 2004, Kanamori and Rice 2005, Mayeda et al. 2005, Abercrombie and Rice 2005, Kato 2009, Oth 2013, Malagnini et al. 2014b, Baltay et al. 2014) and iv) the formation of clusters related to earthquake prediction (Caputo et al. 1977).

Parallel to the increasing quality and quantity of the seismic networks at both the very local scale and regional scale, more seismological datasets became available characterised by a larger range of values and covering a broader interval of magnitudes. However some questions are still open like the accuracy of the parameters, the range of validity of the Gutenberg-Richter law and in particular the range of the $b$ value.

For example, variations of the stress drop have been documented for different depths (Shearer et al. 2006; Asano and Iwata 2011), different strain rates (Hauksson, 2015), by comparing crustal with sub-crustal earthquakes (Oth 2013), intraplate with interplate events (Kanamori and Anderson 1975, Richardson and Solomon 1977, Allmann and Shearer 2009), microearthquakes with strongto-large earthquakes (Patanè et al. 1997, Yamada et al. 2007) or main-shocks from fore- and aftershocks (Andrews 1986, Lindley 1994, Mori et al. 2003, Mayeda et al. 2005, Asano and Iwata 2011), tectonic regimes or focal mechanisms (Cocco and Rovelli 1989, Escudero and Doser 2012, Rovelli and Calderoni 2014, Somei et al. 2014, Hauksson 2015) and even on single faults or fault systems (Ruff 1999, Allmann and Shearer 2007, Asano and Iwata 2011, Oth and Kaiser 2014, Wang et al. 2015).

A major scope of this note is to reconsider some of the open problems such as the range of validity of the most important laws of seismology such as the Gutenberg-Richter law or the Omori law commonly used for representing some earthquake parameters which in turn are used for estimating the seismic risk.

Another goal of this investigation is to verify the possible similarity of comparable and different datasets that is sets of data observed in similar or different geological and tectonic settings, possibly in a similar range of magnitudes and also to verify the stability of the density distribution functions (ddf) of the parameters when using different methods for obtaining the parameters as in the size of the fault generating the earthquake, for example using the method of Brune or the method of Madariaga. An additional scope of our work is to investigate different portions of the dataset of each parameter, and possibly confirm the practical validity of 
the commonly used power laws which have been suggested and used since long for the source radius $r_{0}$ and for the stress drop $\Delta \sigma$ and see their largest possible range of validity.

To these aims, we investigate and possibly confirm the validity of the power laws suggested for some seismological parameters which are largely used for describing geometrically and physically the earthquake. In particular, we analyse various seismological datasets collected in different geological and tectonic settings as well as at different time and space scales, like major seismic sequences, regional background seismicity, aftershock sequences, microseismic data, seismic swarms and induced seismicity (Table 1). We investigate these datasets in terms of statistical distribution of single parameters focusing on stress drop, scalar seismic moment and source radius. More specifically, we obtain the ddfs of each parameter verifying the range of validity of the regression curves. We also analyse the correlations between the investigated parameters by comparing the slope of the ddfs for each dataset.

\section{Datasets and analyses}

Numerous publications exist providing datasets of one or more of the seismological parameters we want to analyse. Relatively less however are those providing both stress drop and seismic moment (or moment magnitude) independently obtained and even much less those that also explicitely list the radius values. Accordingly and following a systematic search in the literature, we selected 26 internally homogeneous datasets. Although several other datasets are available in the literature, we considered only those containing a minimum number of events sufficient to provide a reasonably accurate statistical analysis.

In Table 1, it is reported a synthetic description of the geological and tectonic setting, the type of observed seismicity as well as the recording network and its relative instrumentation. For more details on the specific datasets, the reader should refer to the original papers.

Table 1: General Information of the Analysed Datasets

\begin{tabular}{|c|c|c|c|c|}
\hline authors & $\begin{array}{l}\# \\
\text { ethqs }\end{array}$ & geological and tectonic setting & observed seismicity & instrumentation/network \\
\hline $\begin{array}{l}\text { (1) Kwiatek et al. } \\
\text { (2011) }\end{array}$ & 1220 & $\begin{array}{l}\text { Pink Green Diorite dike, Mpo- } \\
\text { neng Gold Mine, Carletonville, } \\
\text { South Africa }\end{array}$ & $\begin{array}{l}\text { postblasting nano- and picoseismici- } \\
\text { ty, including aftershock sequence of } \\
\text { an } M_{w} 1.9 \text { event }\end{array}$ & $\begin{array}{l}\text { AE sensors calibrated with } 3 \mathrm{C} \text { accelerome- } \\
\text { ters; Japanese-German Underground Acous- } \\
\text { tic emission Research in South Africa } \\
\text { (JAGUARS) network }\end{array}$ \\
\hline $\begin{array}{l}\text { (2) Gibowicz et al. } \\
\text { (1991) }\end{array}$ & 155 & $\begin{array}{l}\text { Lac du Bonnet Granite Batho- } \\
\text { lith (massive gray granite, } \\
\text { Canadian shield),M Lac du } \\
\text { Bonnet, Manitoba, Canada) }\end{array}$ & $\begin{array}{l}\text { nano- and picoseismicity surrounding } \\
\text { the excavation of a shaft }\end{array}$ & $\begin{array}{l}\text { seismic sensors (accelerometers and hydro- } \\
\text { phones) installed in dedicated boreholes, } \\
\text { Underground Research Laboratory }\end{array}$ \\
\hline (3) Jost et al. (1998) & 157 & $\begin{array}{l}\text { intraplate compressional set- } \\
\text { ting, west Bohemian Massif, } \\
\text { Germany }\end{array}$ & $\begin{array}{l}\text { fluid injection-induced seismicity in } \\
\text { the KTB Project borehole }\end{array}$ & $\begin{array}{l}3 \mathrm{C} \text { seismometer at } 4 \mathrm{~km} \text { depth and tempo- } \\
\text { rary network at surface }\end{array}$ \\
\hline $\begin{array}{l}\text { (4) Tusa et al. } \\
\text { (2006b) }\end{array}$ & 200 & $\begin{array}{l}\text { volcanotectonic setting }(0.5- \\
15.5 \mathrm{~km}), \text { Mount St. Helen, } \\
\text { USA }\end{array}$ & $\begin{array}{l}\text { selected microearthquakes in the } \\
\text { period } 1995-1998\end{array}$ & Pacific Northwest Seismographic Network \\
\hline $\begin{array}{l}\text { (5) Stork and Ito } \\
\text { (2004) }\end{array}$ & 68 & $\begin{array}{l}\text { transcurrrent regime, Western } \\
\text { Nagano, Japan }\end{array}$ & $\begin{array}{l}\text { small earthquakes in the period May- } \\
\text { October } 1999\end{array}$ & $3 \mathrm{C}$ seismometer in a $800 \mathrm{~m}$-deep borehole \\
\hline (6) Jin et al. (2000) & 102 & $\begin{array}{l}\text { Atotsugawa fault zone, Hok- } \\
\text { kaido, central Japan }\end{array}$ & $\begin{array}{l}\text { selected microseismicity in the period } \\
1995-1997\end{array}$ & $\begin{array}{l}\text { 3C short-period velocity seismometers } \\
\text { operated by KTJnet }\end{array}$ \\
\hline $\begin{array}{l}\text { (7) Tusa et al. } \\
\text { (2006a) }\end{array}$ & 135 & $\begin{array}{l}\text { Hyblean Foreland, SE Sicily, } \\
\text { Italy }\end{array}$ & 1994-2001 local microseismicity & $\begin{array}{l}\text { 3C short-period seismometers of Southeast- } \\
\text { ern Sicily Seismic Network by INGV }\end{array}$ \\
\hline $\begin{array}{l}\text { (8) Hauksson et al. } \\
\text { (2013) }\end{array}$ & 290 & $\begin{array}{l}\text { Brawley Seismic Zone, } \\
\text { Imperial Valley, South } \\
\text { California, USA }\end{array}$ & 2012 Brawley earthquake swarm & USGS, Caltech and SCSN \\
\hline $\begin{array}{l}\text { (9) Kumar et al. } \\
\text { (2013) }\end{array}$ & 135 & $\begin{array}{l}\text { collisional setting in corre- } \\
\text { spondence of the } 1905 \text { Kangra } \\
\text { epicentral area, NW Himalaya }\end{array}$ & $\begin{array}{l}\text { micro- and low-magnitude earth- } \\
\text { quakes in the period 2004-2005 }\end{array}$ & $\begin{array}{l}\text { local network with both permanent and } \\
\text { temporary stations }\end{array}$ \\
\hline $\begin{array}{l}\text { (10) Hough and } \\
\text { Dreger (1995) }\end{array}$ & 84 & $\begin{array}{l}\text { Coachella Valley segment of } \\
\text { the San Andreas Fault, Califor- } \\
\text { nia, USA }\end{array}$ & $\begin{array}{l}\text { aftershocks sequence of the Mw 6.1, } \\
23 \text { April } 1992 \text { Joshua Tree earth- } \\
\text { quake, California }\end{array}$ & $\begin{array}{l}\text { broadband TERRAscope stations and porta- } \\
\text { ble instruments }\end{array}$ \\
\hline $\begin{array}{l}\text { (11) Giampiccolo et } \\
\text { al. (2008) }\end{array}$ & 89 & $\begin{array}{l}\text { Siculo-Calabro Rift Zone, } \\
\text { southern Italy }\end{array}$ & $\begin{array}{l}\text { minor seismicity in the Gioia Tauro } \\
\text { Basin during the period 1985-1994 }\end{array}$ & 11 stations temporary seismic network \\
\hline 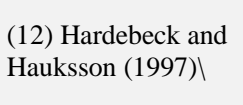 & 301 & $\begin{array}{l}\text { a branch of the San Andreas } \\
\text { Fault system, South California, } \\
\text { USA }\end{array}$ & $\begin{array}{l}\text { aftershocks sequence of the Mw } 6.7 \text {, } \\
\text { January } 17,1994 \text { Northridge earth- } \\
\text { quake, California }\end{array}$ & $\begin{array}{l}\text { broadband velocity seismometers operated } \\
\text { by Southern California Seismic Network }\end{array}$ \\
\hline $\begin{array}{l}\text { (13) Calderoni et al. } \\
(2005)\end{array}$ & 118 & $\begin{array}{l}\text { compressional setting, southern } \\
\text { Tyrrhenian Sea, Italy }\end{array}$ & $\begin{array}{l}\text { aftershocks sequence of the Mw 5.9, } 6 \\
\text { September } 2002 \text { Palermo earthquake, } \\
\text { Italy }\end{array}$ & $\begin{array}{l}\text { high-dynamic-range acquisition systems in } \\
\text { rock stations near Palermo }\end{array}$ \\
\hline $\begin{array}{l}\text { (14) Allen et al. } \\
\text { (2004) }\end{array}$ & 91 & $\begin{array}{l}\text { compressive intraplate setting, } \\
\text { southeastern Australia }\end{array}$ & $\begin{array}{l}\text { best constrained } M<5 \text { earthquakes in } \\
\text { the period 1993-2001 }\end{array}$ & $\begin{array}{l}\text { ES\&S Seismology Research Centre, Mel- } \\
\text { bourne }\end{array}$ \\
\hline $\begin{array}{l}\text { (15) Giampiccolo et } \\
\text { al. (2007) }\end{array}$ & 66 & $\begin{array}{l}\text { volcano-tectonic setting with } \\
\text { strong lateral heterogeneities, } \\
\text { Mt. Etna, Sicily, Italy }\end{array}$ & $\begin{array}{l}\text { shallow crust }(<5 \mathrm{~km}) \text { microseismicity } \\
\text { during the } 2001 \text { and } 2002-2003 \text { flank } \\
\text { eruptions }\end{array}$ & $\begin{array}{l}\text { both } 3 \mathrm{C} \text { and } 1 \mathrm{C} \text { short-period velocity seis- } \\
\text { mometers belonging to the permanent net- } \\
\text { work of INGV }\end{array}$ \\
\hline $\begin{array}{l}(16,17) \text { Bora et al. } \\
(2013)\end{array}$ & 120 & $\begin{array}{l}\text { Shillong-Mikir plateau, Assam } \\
\text { Valley-Arunachal Himalaya, }\end{array}$ & $\begin{array}{l}\text { local earthquakes in the period 2001- } \\
2008\end{array}$ & $\begin{array}{l}\text { vertical component broadband seismometers } \\
\text { operated by NEIST-J and NGRI-H }\end{array}$ \\
\hline
\end{tabular}




\begin{tabular}{|c|c|c|c|c|}
\hline (Madariaga model) & & northeast India & & \\
\hline $\begin{array}{l}\text { (18) Calderoni et al. } \\
(2013)\end{array}$ & 64 & $\begin{array}{l}\text { inner Apennines extensional } \\
\text { province, central Italy }\end{array}$ & $\begin{array}{l}2009 \text { L'Aquila, Italy, seismic se- } \\
\text { quence }\end{array}$ & broad-band seismographs, INGV network \\
\hline $\begin{array}{l}(20) \text { Oth }(2013) \\
(>30 \mathrm{~km})\end{array}$ & 2013 & $\begin{array}{l}\text { subcrustal, subduction-related } \\
\text { setting, Japan }\end{array}$ & $\begin{array}{l}\text { 1996-2011 seismicity across the Japan } \\
\text { archipelago }\end{array}$ & $\begin{array}{l}\text { boreholes recordings from K-NET and KiK- } \\
\text { net networks operated by NIED, Japan }\end{array}$ \\
\hline $\begin{array}{l}\text { (21) Oth and Kaiser } \\
\text { (2014) }\end{array}$ & 205 & $\begin{array}{l}\text { intraplate transcurrent setting, } \\
\text { New Zealand }\end{array}$ & $\begin{array}{l}\text { main- and aftershoks of the } 2010- \\
2011 \text { Canterbury, New Zealand }\end{array}$ & New Zealand GeoNet monitoring network \\
\hline $\begin{array}{l}\text { (22) Somei et al. } \\
\text { (2014) }\end{array}$ & 298 & $\begin{array}{l}\text { mostly collisional setting, Nii- } \\
\text { gata-Kobe Tectonic Zone, } \\
\text { Hokkaido, Japan }\end{array}$ & $\begin{array}{l}17 \text { inland crustal sequences in Japan } \\
\text { including mainshocks }\end{array}$ & $\begin{array}{l}\text { K-NET and KiK-net networks operated by } \\
\text { NIED, Japan }\end{array}$ \\
\hline $\begin{array}{l}\text { (23) Ameri et al. } \\
\text { (2011) }\end{array}$ & 110 & $\begin{array}{l}\text { inner Apennines extensional } \\
\text { province, central Italy }\end{array}$ & $\begin{array}{l}\text { aftershocks sequence of the Mw } 6.3 \text {, } \\
\text { April 6, } 2009 \text { L'Aquila earthquake, } \\
\text { Italy }\end{array}$ & $\begin{array}{l}\text { temporary network (velocimetric and accel- } \\
\text { erometric stations) operadet by INGV-Rome } \\
\text { and GFZ-Potsdam }\end{array}$ \\
\hline $\begin{array}{l}\text { (24) Baltay et al. } \\
\text { (2011) }\end{array}$ & 88 & $\begin{array}{l}\text { compressive settings, Northern } \\
\text { Honshu, Japan }\end{array}$ & $\begin{array}{l}\text { four earthquake sequences including } \\
\text { mainshocks }\end{array}$ & $\begin{array}{l}\text { boreholes recordings from Hi-net broadband } \\
\text { and KiK-net strong motion networks }\end{array}$ \\
\hline $\begin{array}{l}\text { (25) Mayeda and } \\
\text { Walter (1996) }\end{array}$ & 94 & $\begin{array}{l}\text { different crustal rocks }(1-30 \\
\mathrm{km}-\mathrm{deep}, \text { Basin and Range } \\
\text { extensional Province and Cali- } \\
\text { fornia }\end{array}$ & $\begin{array}{l}\text { all } M>5.0 \text { mainshocks and selected } \\
\text { aftershocks in the period } 1988-1994 \\
\text { and selected events out of the period }\end{array}$ & 3C broad-band seismographs \\
\hline $\begin{array}{l}\text { (26) Garcia-Garcìa } \\
\text { et al. (1996) }\end{array}$ & 95 & $\begin{array}{l}\text { tensile regime in the Granada } \\
\text { Basin, southern Spain }\end{array}$ & $\begin{array}{l}\text { selected good signal-to-noise ration } \\
\text { microearthquakes }\end{array}$ & $\begin{array}{l}10 \text { short-period stations of the Andalusian } \\
\text { Seismic Network }\end{array}$ \\
\hline
\end{tabular}

In Table 2, the range of values of each dataset and the median for the analyzed parameters are reported. In few cases (marked in Table 2) the authors provide only the moment magnitude that we converted in seismic moment using the Kanamori and Anderson (1975) empirical relationship.

For several datasets the authors additionally provided the fault's radius $\left(\mathrm{r}_{0}\right)$, which are also listed in Table 2 . In some datasets the source radius is not esplicitly listed but the authors provide all necessary information for obtaining it by inverting from the seismic moment and the stress drop (Eshelby 1957). For the purpose of this paper, we thus completed the database by calculating the fault's radius assuming that the fault is circular and $\lambda=\mu$ for the Lamé elastic parameters. These values are also listed in Table 2 but reported in italics.
For each dataset and for each parameter investigated in this paper, we analysed their distribution. At this regard, we preferred the use of the density distribution function, ddf, instead of the more commonly used cumulative distribution function. This is because the former function provides an information of the dataset which is local in the time domain, while the latter is a non-local function whose values also include the values of the previous data and possibly the uncertainty. In particular, we focused on the slope value of the regression line. As it is well known, the values of the estimated slopes depend on the choice of the overall interval considered for the dataset, and on the selected width of the cells of the histogram (bins).

Table 2: Range and Median Values of the Analysed Parameters

\begin{tabular}{|c|c|c|c|c|c|c|c|c|}
\hline authors & $\begin{array}{l}\# \\
\text { ethqs }\end{array}$ & $\begin{array}{l}\text { Mo } \\
\min -\max \\
{[\mathrm{N} . \mathrm{m}]}\end{array}$ & $\begin{array}{l}\text { Mo } \\
\text { median } \\
{[\mathrm{N} . \mathrm{m}]}\end{array}$ & $\begin{array}{l}\text { Mo } \\
\text { mean } \\
{[\text { N.m] }}\end{array}$ & $\begin{array}{l}\Delta \sigma \\
\min -\max \\
{[\mathrm{Pa}]}\end{array}$ & $\begin{array}{l}\Delta \sigma \\
\text { median } \\
{[\mathrm{Pa}]}\end{array}$ & $\begin{array}{l}\text { Radius } \\
\min -\max \\
{[\mathrm{m}]}\end{array}$ & $\begin{array}{l}\text { radius } \\
\text { median } \\
{[\mathrm{m}]}\end{array}$ \\
\hline (1) Kwiatek et al. (2011) & 1220 & $8.1 \cdot 10^{02}-6.8 \cdot 10^{07}$ & $3.1 \cdot 10^{04}$ & $5.3 \cdot 10^{05}$ & $1.2 \cdot 10^{05}-3.0 \cdot 10^{07}$ & $1.0 \cdot 10^{06}$ & $0.08-1.30$ & 0.23 \\
\hline (2) Gibowicz et al. (1991) & 155 & $4.7 \cdot 10^{03}-3.0 \cdot 10^{06}$ & $9.9 \cdot 10^{04}$ & $2.4 \cdot 10^{05}$ & $3.7 \cdot 10^{04}-3.1 \cdot 10^{06}$ & $3.7 \cdot 10^{05}$ & $0.24-0.91$ & 0.5 \\
\hline (3) Jost et al. (1998) & 157 & $3.1 \cdot 10^{10}-2.2 \cdot 10^{12}$ & $2.5 \cdot 10^{08}$ & $1.5 \cdot 10^{10}$ & $7.4 \cdot 10^{03}-1.1 \cdot 10^{04}$ & $1.4 \cdot 10^{04}$ & $17-251$ & 18 \\
\hline (4) Tusa et al. (2006b) & 200 & $3.1 \cdot 10^{10}-2.2 \cdot 10^{12}$ & $3.1 \cdot 10^{11}$ & $4.5 \cdot 10^{11}$ & $1.0 \cdot 10^{03}-6.6 \cdot 10^{05}$ & $2.5 \cdot 10^{04}$ & $89-365$ & 180 \\
\hline (5) Stork and Ito (2004) & 68 & $9.1 \cdot 10^{07}-1.2 \cdot 10^{08}$ & $1.0 \cdot 10^{11}$ & $7.4 \cdot 10^{11}$ & $3.6 \cdot 10^{04}-3.1 \cdot 10^{07}$ & $6.4 \cdot 10^{05}$ & $18-162$ & 47 \\
\hline (6) Jin et al. (2000) & 102 & $4.1 \cdot 10^{10}-2.9 \cdot 10^{14}$ & $5.9 \cdot 10^{11}$ & $7.7 \cdot 10^{12}$ & $1.7 \cdot 10^{04}-1.2 \cdot 10^{07}$ & $3.0 \cdot 10^{05}$ & $54-385$ & 98 \\
\hline (7) Tusa et al. (2006a) & 135 & $1.7 \cdot 10^{10}-1.8 \cdot 10^{13}$ & $7.7 \cdot 10^{11}$ & $2.2 \cdot 10^{12}$ & $2.0 \cdot 10^{03}-7.8 \cdot 10^{05}$ & $2.4 \cdot 10^{04}$ & $148-516$ & 227 \\
\hline (8) Hauksson et al. (2013) & 290 & $9.2 \cdot 10^{10}-3.5 \cdot 10^{16}(*)$ & $2.1 \cdot 10^{12}$ & $4.1 \cdot 10^{14}$ & $3.1 \cdot 10^{03}-4.8 \cdot 10^{06}$ & $2.4 \cdot 10^{05}$ & 29-2640 & 161 \\
\hline (9) Kumar et al. (2013) & 135 & $1.2 \cdot 10^{11}-8.5 \cdot 10^{15}(*)$ & $2.2 \cdot 10^{12}$ & $1.4 \cdot 10^{14}$ & $8.0 \cdot 10^{03}-2.7 \cdot 10^{06}$ & $1.0 \cdot 10^{05}(+)$ & $107-1113$ & 209 \\
\hline $\begin{array}{l}\text { (10) Hough and Dreger } \\
\text { (1995) }\end{array}$ & 84 & $2.1 \cdot 10^{11}-2.2 \cdot 10^{16}$ & $4.4 \cdot 10^{12}$ & $7.3 \cdot 10^{14}$ & $5.5 \cdot 10^{03}-1.7 \cdot 10^{07}$ & $8.9 \cdot 10^{05}(+)$ & $40-1241$ & 163 \\
\hline $\begin{array}{l}\text { (11) Giampiccolo et al. } \\
\text { (2008) }\end{array}$ & 89 & $1.6 \cdot 10^{12}-4.0 \cdot 10^{14}$ & $6.3 \cdot 10^{12}$ & $1.6 \cdot 10^{13}$ & $1.5 \cdot 10^{04}-7.5 \cdot 10^{06}$ & $1.7 \cdot 10^{05}$ & $55-467$ & 265 \\
\hline $\begin{array}{l}\text { (12) Hardebeck and } \\
\text { Hauksson (1997) }\end{array}$ & $\begin{array}{l}301 \\
(\wedge)\end{array}$ & $5.6 \cdot 10^{12}-7.1 \cdot 10^{14}$ & $1.6 \cdot 10^{13}$ & $4.8 \cdot 10^{13}$ & $3.9 \cdot 10^{03}-7.0 \cdot 10^{06}$ & $1.1 \cdot 10^{05}$ & 209-719 & 415 \\
\hline (13) Calderoni et al. (2005) & $\begin{array}{l}118 \\
\left({ }^{\circ}\right)\end{array}$ & $2.0 \cdot 10^{12}-2.3 \cdot 10^{15}$ & $1.8 \cdot 10^{13}$ & $1.1 \cdot 10^{14}$ & $1.0 \cdot 10^{04}-5.3 \cdot 10^{06}$ & $5.0 \cdot 10^{05}$ & $146-923$ & 270 \\
\hline
\end{tabular}




\begin{tabular}{|c|c|c|c|c|c|c|c|c|}
\hline (14) Allen et al. (2004) & 91 & $7.9 \cdot 10^{11}-7.0 \cdot 10^{15}$ & $1.8 \cdot 10^{13}$ & $1.7 \cdot 10^{14}$ & $6.0 \cdot 10^{04}-9.5 \cdot 10^{06}$ & $7.1 \cdot 10^{05}$ & $110-750$ & 220 \\
\hline $\begin{array}{l}\text { (15) Giampiccolo et al. } \\
\text { (2007) }\end{array}$ & 66 & $1.3 \cdot 10^{13}-2.0 \cdot 10^{15}$ & $1.2 \cdot 10^{14}$ & $3.3 \cdot 10^{14}$ & $2.3 \cdot 10^{05}-4.3 \cdot 10^{06}$ & $1.1 \cdot 10^{06}$ & 204-973 & 337 \\
\hline $\begin{array}{l}\text { (16) Bora et al. (2013) } \\
\text { (Brune model) }\end{array}$ & & & & & $4.0 \cdot 10^{05}-9.0 \cdot 10^{07}$ & $1.0 \cdot 10^{07}$ & $134-268$ & 179 \\
\hline (17) & 120 & $9.5 \cdot 10^{12}-3.4 \cdot 10^{15}$ & $1.8 \cdot 10^{14}$ & $3.1 \cdot 10^{14}$ & & & & \\
\hline $\begin{array}{l}\text { (17) Bora et al. (2013) } \\
\text { (Madariaga model) }\end{array}$ & & & & & $7.0 \cdot 10^{05}-1.0 \cdot 10^{08}$ & $2.0 \cdot 10^{07}$ & $116-232$ & 155 \\
\hline (18) Calderoni et al. (2013) & 64 & $7.8 \cdot 10^{13}-1.9 \cdot 10^{18}(*)$ & $2.5 \cdot 10^{14}$ & $3.6 \cdot 10^{16}$ & $4.1 \cdot 10^{05}-1.7 \cdot 10^{07}$ & $2.0 \cdot 10^{06}$ & $197-4520$ & 431 \\
\hline $\begin{array}{l}\text { (19) Oth }(2013) \\
(<30 \mathrm{~km})\end{array}$ & 1946 & $1.4 \cdot 10^{13}-7.8 \cdot 10^{19}$ & $4.4 \cdot 10^{14}$ & $1.0 \cdot 10^{17}$ & $1.0 \cdot 10^{05}-1.2 \cdot 10^{08}$ & $1.4 \cdot 10^{06}$ & $61-18024$ & 543 \\
\hline $\begin{array}{l}\text { (20) Oth }(2013) \\
(>30 \mathrm{~km})\end{array}$ & 2013 & $5.5 \cdot 10^{13}-8.7 \cdot 10^{20}$ & $2.5 \cdot 10^{15}$ & $6.5 \cdot 10^{17}$ & $5.0 \cdot 10^{05}-1.4 \cdot 10^{08}$ & $1.1 \cdot 10^{07}$ & $125-14861$ & 457 \\
\hline (22) Somei et al. (2014) & 298 & $8.1 \cdot 10^{13}-3.3 \cdot 10^{19}$ & $7.1 \cdot 10^{14}$ & $4.5 \cdot 10^{17}$ & $1.0 \cdot 10^{04}-2.6 \cdot 10^{07}$ & $5.7 \cdot 10^{05}$ & $278-25000$ & 909 \\
\hline (23) Ameri et al. (2011) & 110 & $1.1 \cdot 10^{14}-3.1 \cdot 10^{17}(*)$ & $1.2 \cdot 10^{15}$ & $8.9 \cdot 10^{15}$ & $3.2 \cdot 10^{05}-6.3 \cdot 10^{07}$ & $3.2 \cdot 10^{06}$ & 189-2110 & 564 \\
\hline (24) Baltay et al. (2011) & 88 & $1.6 \cdot 10^{12}-2.7 \cdot 10^{19}$ & $2.3 \cdot 10^{15}$ & $6.3 \cdot 10^{17}$ & $1.1 \cdot 10^{05}-3.7 \cdot 10^{07}$ & $6.7 \cdot 10^{06}$ & $39-10400$ & 532 \\
\hline $\begin{array}{l}\text { (25) Mayeda and Walter } \\
\text { (1996) }\end{array}$ & 94 & $2.1 \cdot 10^{12}-1.2 \cdot 10^{20}(*)$ & $1.4 \cdot 10^{16}$ & $2.5 \cdot 10^{18}$ & $1.0 \cdot 10^{05}-2.5 \cdot 10^{07}$ & $2.5 \cdot 10^{06}$ & $283-15320$ & 1665 \\
\hline $\begin{array}{l}\text { (26) Garcia-Garcìa et al. } \\
\text { (1996) }\end{array}$ & 95 & $2.2 \cdot 10^{16}-1.1 \cdot 10^{19}$ & $2.8 \cdot 10^{17}$ & $9.7 \cdot 10^{17}$ & $1.5 \cdot 10^{03}-2.6 \cdot 10^{05}$ & $1.5 \cdot 10^{04}$ & $140-400$ & 210 \\
\hline
\end{tabular}

$\left(^{*}\right)$ calculated from the moment magnitude; $\left({ }^{\wedge}\right)$ provided only 279 stress drop values; $\left({ }^{\circ}\right)$ from SOLU station; $(+)$ mean value between $\Delta \sigma_{\mathrm{P}}$ and $\Delta \sigma_{\mathrm{S}}$.

Relative to the former issue, we systematically, though variably, excluded the tail of the lower values due to the evident undersampling and extended the range in the higher values up to the last bin containing at least 3 data. On the other hand, the width of the cells determines the number of bars in the histogram, that is the number of values on which the ddf is calculated by linear regression in the log-log diagram. In principle, the smaller the bin, the larger their total number, but also the greater the chance that some bin contains few data, say less than three, therefore limiting the overall interval for calculating the ddf as above mentioned.

Following this approach, we made numerous attempts by varying both the lower considered value and the bin size. Accordingly, we selected the ddf and its corresponding slope based on the best combination between the considered number of cells and the values of the $\mathrm{R}^{2}$ test obtained from the linear regression. The log-log power law being expressed as $\log n(:)=a+b \cdot \log (:)$

All selected density distributions are represented in Figures 1, 2 and 3 for $\Delta \sigma, M_{0}$ and $r_{0}$, respectively, together with the calculated regression curves. In Table 3 are reported the $a$ and $b$ coefficients of the selected curves as well as the results of the $\mathrm{R}^{2}$ tests.

It should be remarked that for each dataset the overall interval considered to obtain the ddf is relatively limited, commonly within 1-2 orders of magnitude and in few cases less than one order for the $r_{0}$ datasets, though always with an adeguate number of data. Therefore, the regression curves and hence the corresponding slope values could suffer some degree of uncertainty.

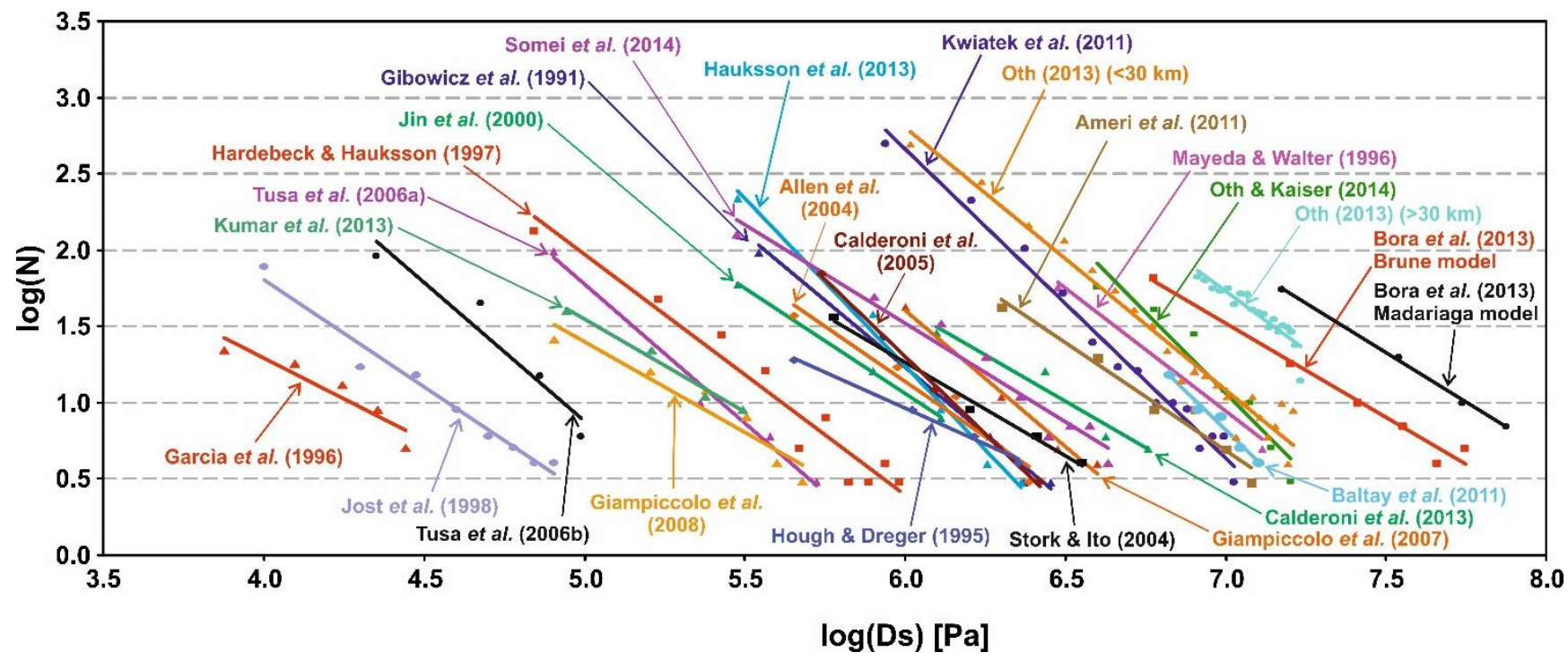

Fig. 1: Stress Drop Distribution for the Investigated Datasets (See Tables 1 and 2) and Corresponding Best-Fit Regression Curves Representative of the Ddf. The Regression Values are reported in Table 3. 


\section{Parameters distribution and correlations}

\subsection{Stress drop density distribution}

The analysis of the statistical distributions shows that the ddf slopes of the different datasets range between -2.20 and -1.22 . Plotting the slope values versus the median of the stress drop for each dataset (Table 3 and Figure 4), we find a practically nul statistical correlation (ca. 0.50) among the two parameters. On the other hand, in a range of almost four orders of magnitude of the stress drop $\left(10^{4}-10^{8} \mathrm{~Pa}\right)$, the slope of the different datasets consistently varies between ca. -1 and something less than -2 . Such correlation would also imply that the ddf of the stress drop is likely not a power law.
We don't know yet if the apparent variability of the estimated slopes even in a same region (for example, California; labels 8, 10 and 12 in Figure 4) is due to the complexity of the seismogenic phenomenon which depends on so many parameters which are not yet considered or to the lack of accuracy of the data which however are recorded and studied with the best technologies. For instance, this variability could be due to the age of the crustal volume, its tectonic evolution, the associated inherited fracturing inducing different density distributions of the size of the faults, the thermal history and the consequent geothermal gradient, the seismogenic depth, the different rate of stress accumulation due to the broader geodynamic setting and the rheological properties in general. Althouhg the datasets collected in transcurrent settings show a slightly larger variability relative to the compressional one (Figure 4), the tectonic regime does not seem to be a crucial factor at this regard.

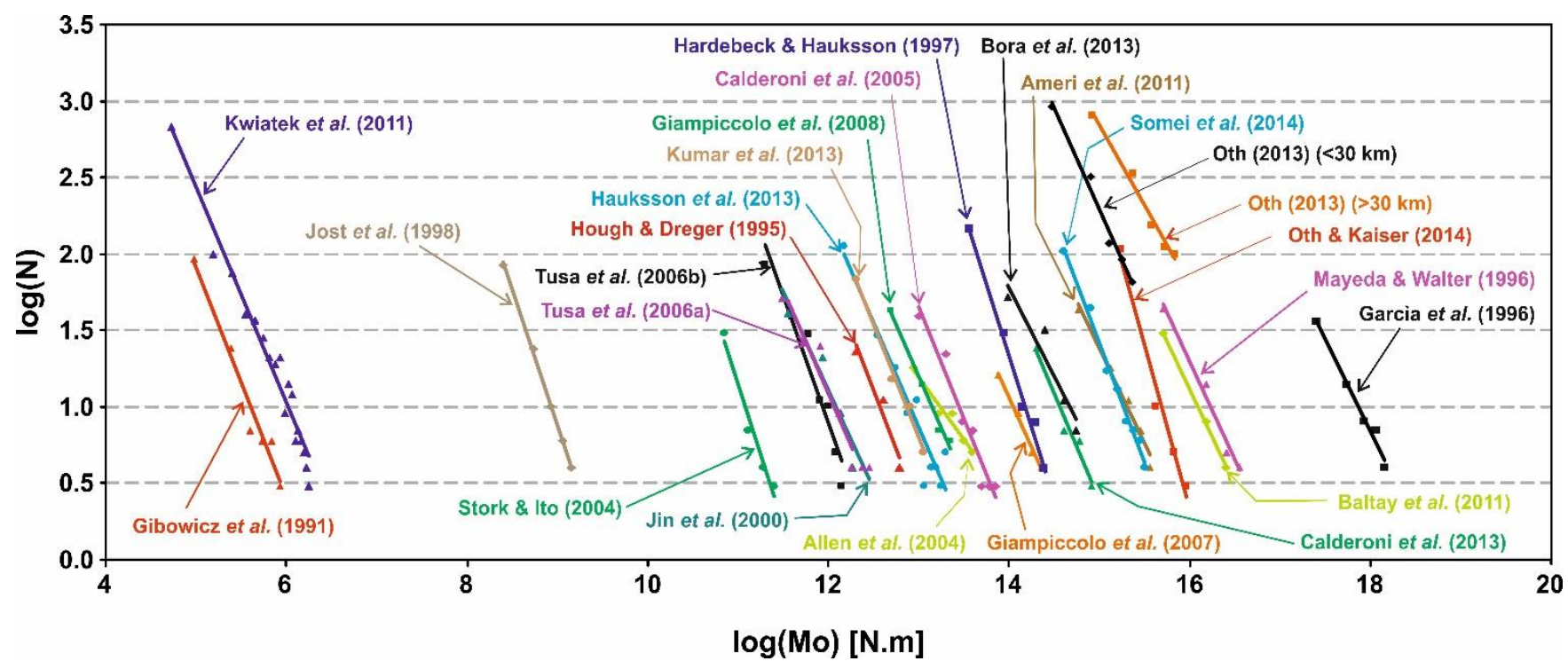

Fig. 2: Seismic Moment Distribution for the Investigated Datasets (See Tables 1 and 2) and Corresponding Bet-Fit Regressione Curves Representative of the Ddf. the Regression Values are Reported in Table 3.

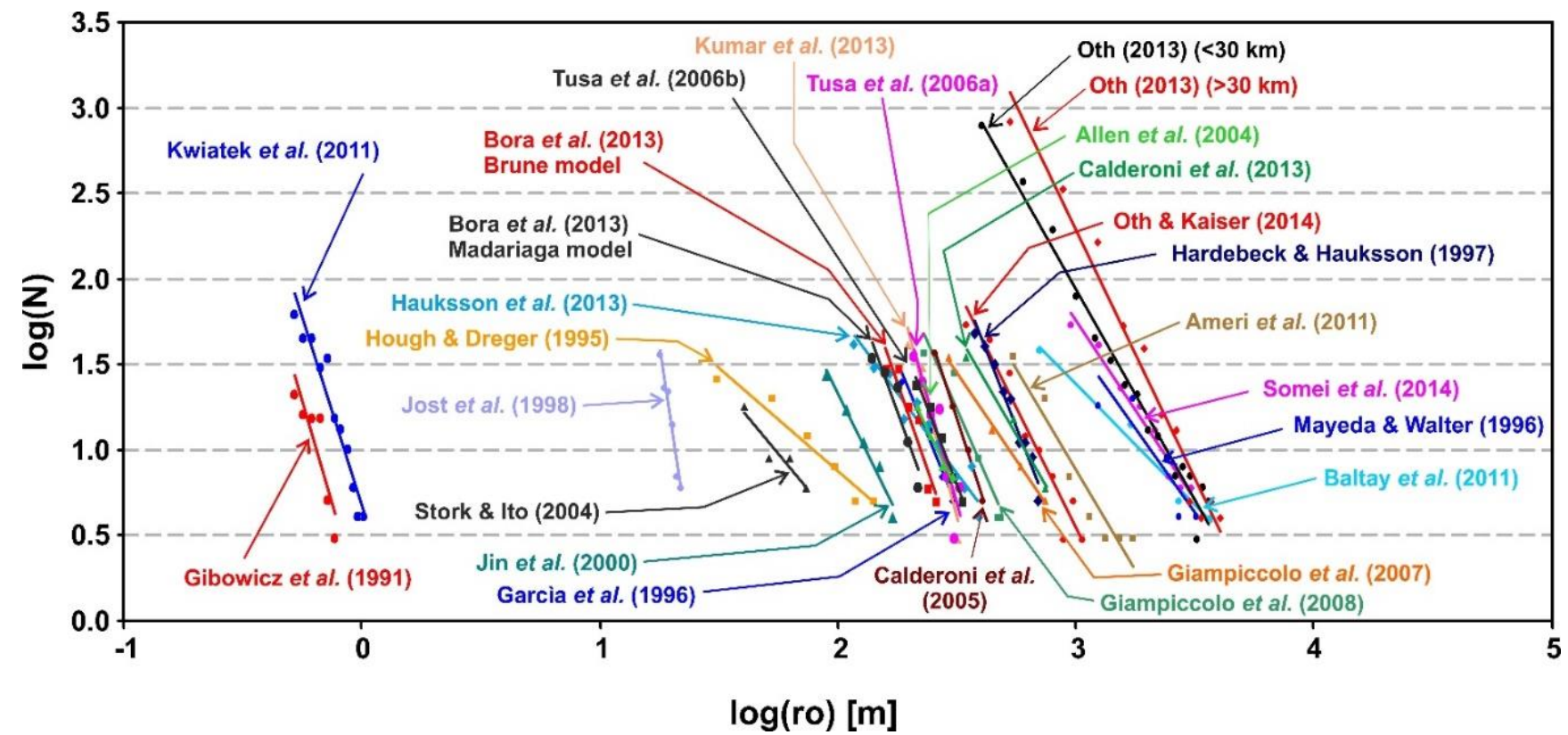

Fig. 3: Faults Radius Distribution for the Investigated Datasets (See Tables 1 and 2) and Corresponding Bet-Fit Regressione Curves Representative of The Ddf. the Regression Values are Reported in Table 3. 


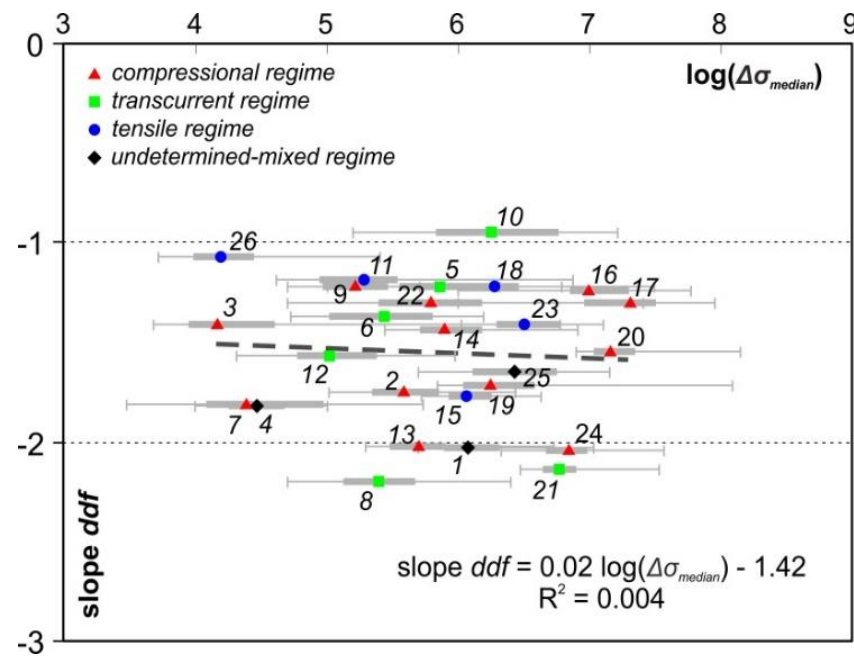

Fig. 4: Stress Drop Median Values versus the Slope of the Corresponding Ddf (Coefficient $\mathrm{B}_{\sigma}$ ). Thick Bars Indicate the First and Third Quartiles, While Thin Ones the Minumum-to-Maximum Range of Analysed Values for Each Dataset. See Also Fig. 1 and Table 3.

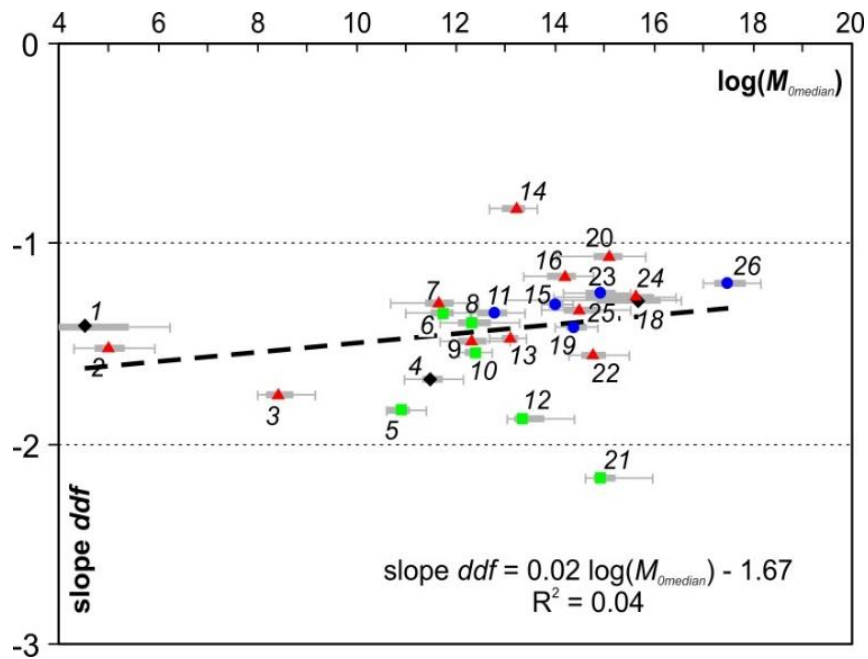

Fig. 5: Scalar Seismic Moment Median Values Versus the Slope of the Corresponding Ddf (Coefficient $\mathrm{B}_{0}$ ). Symbols as in Figure 4. See Also Fig. 2 and Table 3.

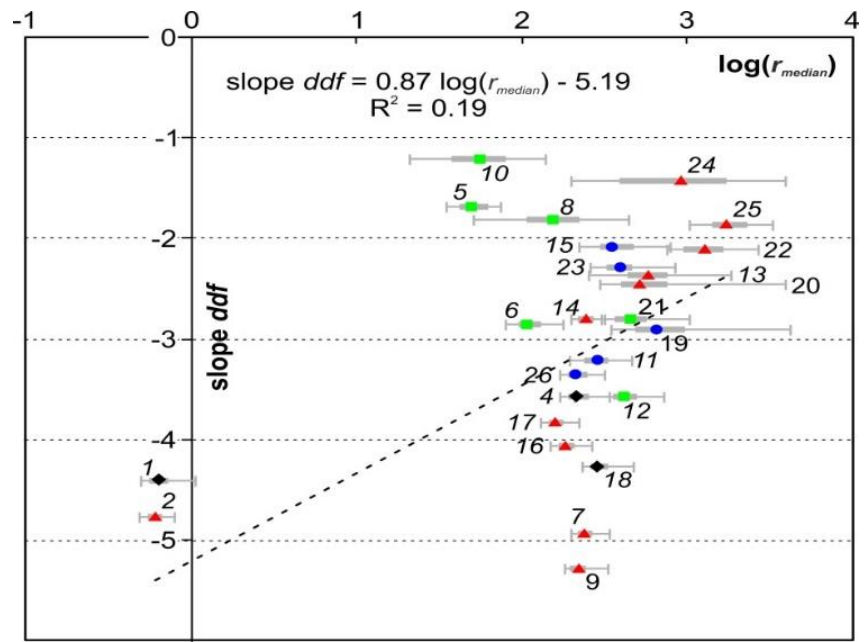

Fig. 6: Source Radius Median Values Versus the Slope of the Corresponding Ddf (Coefficient $B_{r}$ ). See Also Symbols as in Fig. 4. See Also Fig. 3 and Table 3.

\subsection{Seismic moment density distribution}

As concerns the statistical distributions of the seismic moments, the analysis shows that the ddf slopes of the different datasets fall within the range -1.16 and -1.87 , notewithstanding the large range of considered moments (from $10^{4}$ to $10^{16}$; Table 3 and Figure 5) and the variety of the investigated regions. Also in this case, the statistical correlation between the slope values and the median of the seismic moments for each dataset is basically nul (0.04), therefore suggesting the lack of correlation between the two parameters. As concerns the different tectonic regimes investigated, we possibly observe slightly steeper slopes for the transcurrent setting (from -1.29 to -2.17) with respect the compressional one (from 0.82 to -1.75 ), while the tensile regime shows the smaller range of values (between -1.19 and -1.41).

\subsection{Radius density distribution}

For the statistical distribution of the source radius we included the datasets esplicitly listed by the authors, but also those implicitly provided, which we could simply calculate by inverting the Eshelby (1957) formula

$r_{0}=\sqrt[3]{\frac{7 \cdot M_{0}}{16 \cdot \Delta \sigma}}$

The corresponding ddfs are represented in Figure 3, while in Table 3 are reported the numerical values. The slopes of the obtained ddfs range between -5.27 and -1.21 . The only exception is represented by the dataset of Jost et al. (1998) having a slope value of 9.17; such an outlier could be correlated to the different origin of the recorded seismicity which is induced by fluid injection, while all other datasets reflect a natural, basically tectonic, stress field. By plotting these values versus the median of the corresponding dataset we do not observe any correlation as confirmed by the low value of the $\mathrm{R}^{2}$ test (Figure 6), even excluding the mining related datasets (Kwiatek et al. 2011, Gibowicz et al. 1991).

The relevance of the slope of the ddfs of the radius is also of relevance for its possible correlation with the maximum magnitude possible in the region; for instance as provided by Caputo (1982) for rift zones.

\subsection{Correlation between $b_{0}$ and $b_{r}$}

For the source radius distribution it has been theoretically suggested that the slope of the ddf of the scalar seismic moment $\left(b_{0}\right)$

$\log \left(\mathrm{n}_{0}\right)=\mathrm{a}_{0}-\mathrm{b}_{0} \cdot \log \left(\mathrm{M}_{0}\right)$

Is related to the slope $b_{r}$ of the ddf calculated for the source radius $\mathrm{r}_{0}$ following the formula (Caputo 1976)

$b_{0}=\left(b_{r}-2\right) / 3$

Which is supposed to be valid for tectonic earthquakes with intermediate magnitudes occurred in the same seismic region and with a wide range of source areas. We would then expect the above relation to be valid only for tectonic earthquakes and not necessarily for volcanic earthquakes or eathquakes occurring in regions very near to volcanic areas, nor for sets of earthquakes with only relatively small or only relatively large magnitudes. Due to the lack of accurate data, the formula has been never verified in the past. In the following we will try to do it.

Since some of our data are of better quality, we tested again the practical validity of the above relationship. Considering the data of Table 3 (see also Figure 4), we see that 9 datasets out of $26(35 \%)$ give values of $b_{0}$ and $b_{r}$ satifying formula [4] with less than $20 \%$ difference (Table 4). 
Table 3: Regression Values of the Analysed Parameters

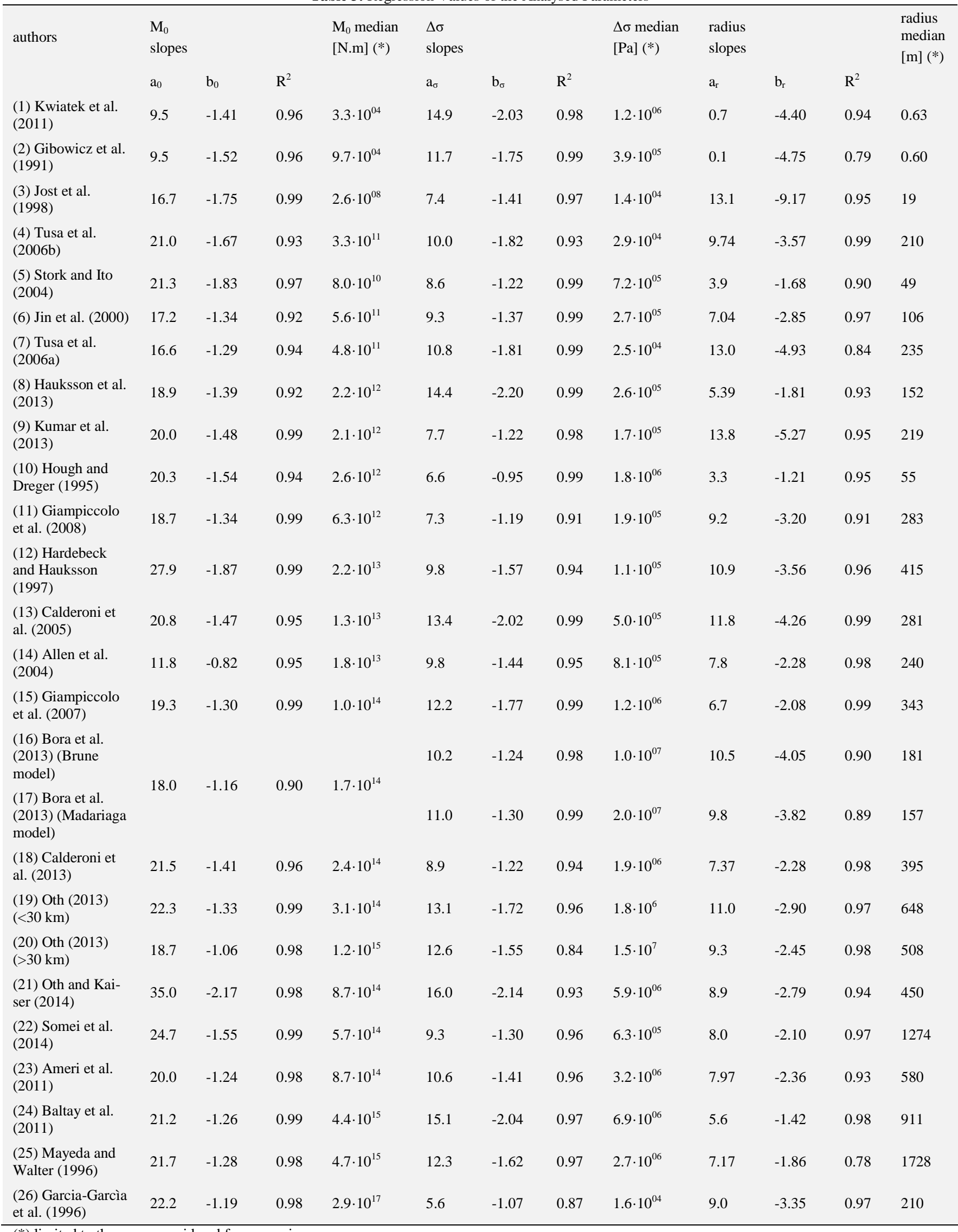

(*) limited to the range considered for regression.

However, if we consider a difference up to $40 \%$, which is still reasonable taking into account all the uncertainties, the total number of datasets satisfying formula [4] becomes 16 (62\%). Since some of our data are of better quality, we tested again the practical validity of the above relationship. Considering the data of Table 3 (see also Figure 4), we see that 9 datasets out of $26(35 \%)$ give values of $b_{0}$ and $b_{r}$ satifying formula [4] with less than $20 \%$ difference (Table 4). However, if we consider a difference up to $40 \%$, 
which is still reasonable taking into account all the uncertainties, the total number of datasets satisfying formula [4] becomes 16 $(62 \%)$. For the datasets showing greater differences, two of them are relative to nanoseismicity from mining test sites (Kwiatek et al. 2011, Gibowicz et al. 1991), where the maximum value of $\mathbf{M}_{0}$ is $3.0 \cdot 10^{6}$ and $6.8 \cdot 10^{7} \mathrm{~N} \cdot \mathrm{m}$, respectively, correponding to a moment magnitude smaller than 0 , which is likely too small for assuming that the earthquakes of these datasets are in the linear range of the Gutenberg-Richter law of small or moderate magnitude of tectonic earthquakes. One dataset is from fluid injection induced seismicity (Jost et al. 1998) characterized by a particularly steep slope $\left(\mathrm{b}_{\mathrm{r}}\right)$ and this could explain the misfit with formula [4], while all the others generally include local micro- or minor seismicity (Tusa et al. 2006a, Bora et al. 2013, Kumar et al. 2013, Calderoni et al. 2005, 2013, Allen et al. 2004, Garcia et al. 1996). We may then conclude that, accepting a $40 \%$ difference between the slope of the ddf of $r_{o}$ obtained directly from the dataset and that estimated from equation [4], all the datasets relative to purely tectonic earthquakes, in the intemediate range of magnitudes, give values of the slope of the ddf of $r_{o}$ in agreement with equation [4].

Table 4: Comparison between $b_{0}$ and $b_{r}$

\begin{tabular}{|c|c|c|c|c|}
\hline authors & $\mathrm{b}_{\mathrm{r}}\left(\mathrm{r}_{0}\right)$ & $\mathrm{b}_{0}\left(\mathrm{M}_{0}\right)$ & $b_{0}\left(b_{r}\right)$ & $2 \Delta b /\left(b_{0}+b_{r}\right)$ \\
\hline Kwiatek et al. (2011) & -4.40 & -1.41 & -2.13 & 0.41 \\
\hline Gibowicz et al. (1991) & -4.75 & -1.52 & -2.25 & 0.39 \\
\hline Jost et al. (1998) & -9.17 & -1.75 & -3.72 & 0.72 \\
\hline Tusa et al. (2006b) & -3.67 & -1.67 & -1.89 & 0.12 \\
\hline Stork and Ito (2004) & -1.68 & -1.83 & -1.23 & -0.39 \\
\hline Jin et al. (2000) & -2.85 & -1.34 & -1.62 & 0.19 \\
\hline Tusa et al. (2006a) & -4.92 & -1.29 & -2.31 & 0.57 \\
\hline Hauksson et al. (2013) & -1.81 & -1.39 & -1.27 & -0.09 \\
\hline Kumar et al. (2013) & -5.27 & -1.48 & -2.42 & 0.48 \\
\hline Hough and Dreger (1995) & -1.21 & -1.54 & -1.07 & -0.36 \\
\hline Giampiccolo et al. (2008) & -3.20 & -1.34 & -1.73 & 0.26 \\
\hline Hardebeck and Hauksson (1997) & -3.56 & -1.87 & -1.85 & -0.01 \\
\hline Calderoni et al. (2005) & -2.28 & -1.47 & -1.43 & -0.03 \\
\hline Allen et al. (2004) & -2.80 & -0.82 & -1.60 & 0.64 \\
\hline Giampiccolo et al. (2007) & -2.08 & -1.30 & -1.36 & 0.05 \\
\hline Bora et al. (2013) (Brune model) & -4.05 & \multirow{2}{*}{-1.16} & -2.02 & 0.54 \\
\hline Bora et al. (2013) (Madariaga model) & -3.82 & & -1.94 & 0.50 \\
\hline Calderoni et al. (2013) & -4.26 & -1.41 & -2.09 & 0.39 \\
\hline Oth $(2013(<30 \mathrm{~km})$ & -2.90 & -1.33 & & \\
\hline Oth $(2013$ (>30 km) & -2.45 & -1.06 & & \\
\hline Oth and Kaiser (2014) & -2.79 & -2.17 & -1.60 & -0.30 \\
\hline Somei et al. (2014) & -2.10 & -1.55 & -1.37 & -0.13 \\
\hline Ameri et al. (2011) & -2.36 & -1.24 & -1.45 & 0.16 \\
\hline Baltay et al. (2011) & -1.42 & -1.26 & -1.14 & -0.10 \\
\hline Mayeda and Walter (1996) & -1.86 & -1.28 & -1.29 & 0.01 \\
\hline Garcia-Garcìa et al. (1996) & -3.35 & -1.19 & -1.78 & 0.40 \\
\hline
\end{tabular}

\subsection{Correlation between stress drop and seismic mo- ment}

Many authors have suggested that the stress drop is nearly independent of seismic moment (Kanamori and Anderson 1975, McGarr 1984, Caputo 1987, Abercrombie 1995) with typical values ranging from $0.1 \mathrm{MPa}$ to $100 \mathrm{MPa}$ for different datasets. In this paper, we also analysed the distribution of the stress drop versus seismic moment (Figure 7) showing that an even larger range of values of stress drops could be observed $\left(10^{3}-10^{8} \mathrm{~Pa}\right)$ if we consider the ensamble of all seismic events (more than 8000) collected for the purpose of this paper and included in the $26 \mathrm{da}-$ tasets. Potential causes for a so wide variability of $\Delta \sigma$ may include differences in tectonic setting, in the amount of water and its pres- sure, variations in rupture velocity, mean temperature and thermal gradients and variations in fault plane normal stress (e.g. Tomic et al. 2009).

Within the broad range of seismic moment values here investigated $\left(10^{3}-10^{21} \mathrm{~N} \cdot \mathrm{m}\right)$, the lack of correlation between the two parameters seems clear. At this regard, the regression curve calculated from all events gives an almost flat slope $(0.07)$ and an $\mathrm{R}^{2}$ of 0.08 (dotted line in Figure 7a). However, if we exclude the subcrustal events of Oth (2013) due to their distinct geological and tectonic setting relative to the other datasets, the slope of the regression becomes practically nil $(0.02)$ as well as the $\mathrm{R}^{2}(0.008$; dashed line in Figure 7a), therefore basically confirming the overall results of Ide and Beroza (2001). 


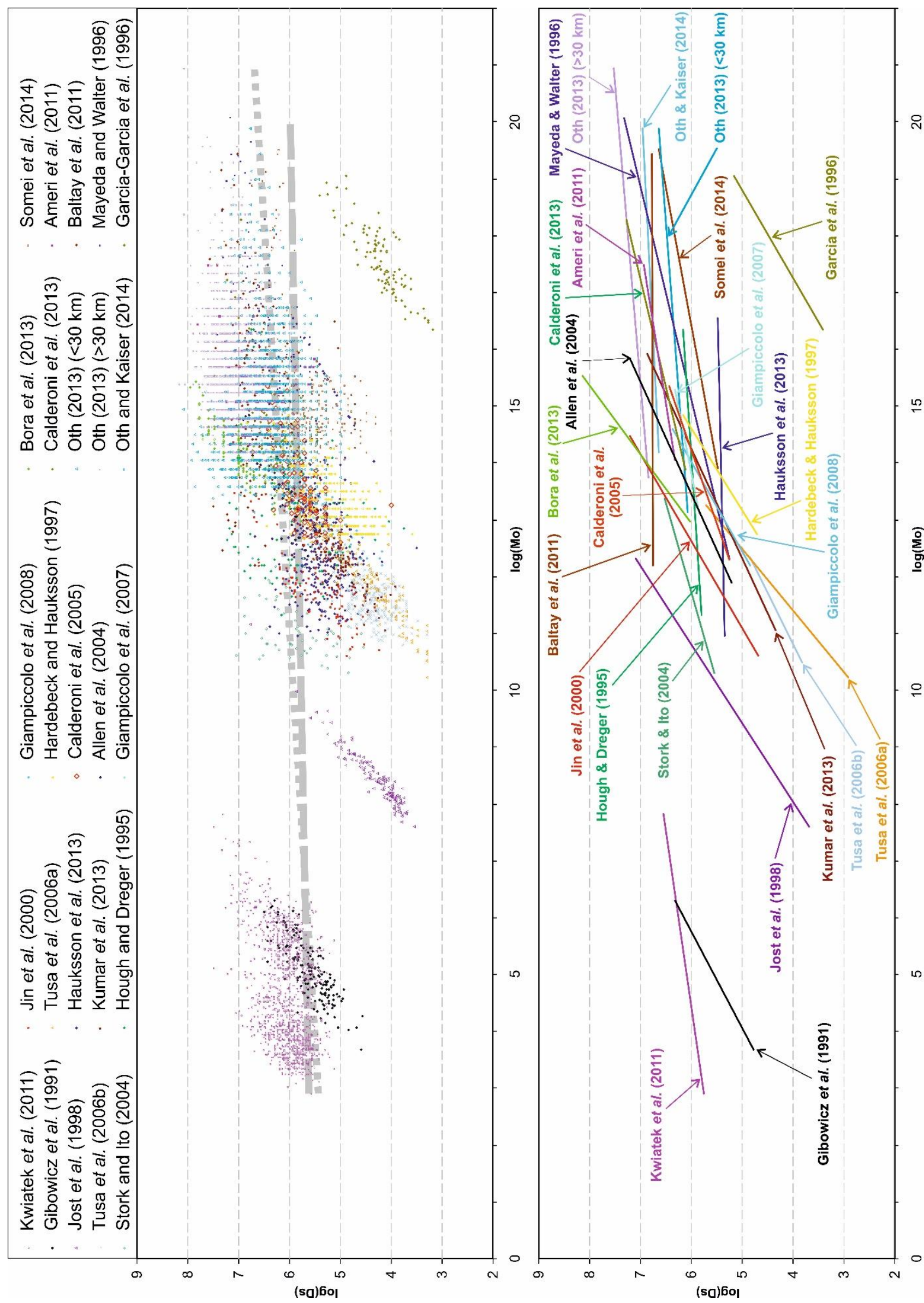

Fig. 7: A) Seismic Moment versus Stress Drop of All Datasets Considered in this Paper (See Table 1). The Dotted Line Represents the Regression Curve From All Data, While in The Dashed One the Subcrustal Events of Oth (2013) Have Been Excluded. B) Regression Curves of Each Dataset (See Table 5 for the Corresponding Numerical Values). 
However, at the local scale when considering individual seismic sequences or 'homogeneous' seismogenic volumes, and notwithstanding the fact that the individual datasets are commonly characterised by a lower variability of the stress drop, generally spanning no more than three orders of magnitude against the five of the overall dataset, in some cases it is possible to observe a clear linear positive correlation among the two parameters (Figure 7b; Table 5). This observation was already suggested in the literature (e.g. Prejean and Ellsworth 2001, Garcìa-Garcìa et al. 2004, Oth 2013, Malagnini et al. 2014a), but the correlation seems to be independent of tectonic setting. Although the largest datasets here considered, like that of Kwiatek et al. (2011) and those of Oth (2013), do not show such trend (Figure 7b; Table 5), this could be due to the merge of different seismic sequences and brittle deformation occurring in heterogeneous crustal volumes, therefore masking the possible existence of positive correlations for distinct subsets as suggested by Oth (2013).

It should be remarked that this difference between global scale catalogues and local scale ones would suggest the possibility of exploiting seismic datasets of restricted regions characterized by uniform tectonic behaviour and geological conditions for predicting the expected ground motion.

Table 5: Regression Values of the Seismic Moment versus Stress Drop

\begin{tabular}{llll}
\hline authors & \multicolumn{3}{l}{ Mo slopes } \\
\hline & $\mathrm{a}$ & $\mathrm{b}$ & $\mathrm{R}^{2}$ \\
(1) Kwiatek et al. (2011) & 5.3 & 0.16 & 0.16 \\
(2) Gibowicz et al. (1991) & 2.6 & 0.59 & 0.65 \\
(3) Jost et al. (1998) & -1.8 & 0.72 & 0.72 \\
(4) Tusa et al. (2006b) & -2.0 & 0.56 & 0.22 \\
(5) Stork and Ito (2004) & 2.25 & 0.32 & 0.09 \\
(6) Jin et al. (2000) & -2.32 & 0.66 & 0.60 \\
(7) Tusa et al. (2006a) & -6.52 & 0.92 & 0.87 \\
(8) Hauksson et al. (2013) & 5.06 & 0.02 & 0.00 \\
(9) Kumar et al. (2013) & -1.39 & 0.52 & 0.73 \\
(10) Hough and Dreger (1995) & 5.01 & 0.07 & 0.01 \\
(11) Giampiccolo et al. (2008) & -2.99 & 0.64 & 0.39 \\
(12) Hardebeck and Hauksson (1997) & -4.06 & 0.69 & 0.44 \\
(13) Calderoni et al. (2005) & 4.98 & 0.39 & 0.50 \\
(14) Allen et al. (2004) & 4.98 & 0.08 & 0.02 \\
(15) Giampiccolo et al. (2007) & 3.04 & 0.21 & 0.20 \\
(16, 17) Bora et al. (2013) & -4.74 & 0.83 & 0.77 \\
(18) Calderoni et al. (2013) & 2.44 & 0.26 & 0.43 \\
(19) Oth (2013) (<30 km) & 4.98 & 0.08 & 0.02 \\
(20) Oth (2013) (>30 km) & 5.55 & 0.09 & 0.06 \\
(21) Oth and Kaiser (2014) & 5.89 & 0.05 & 0.02 \\
(22) Somei et al. (2014) & 2.57 & 0.21 & 0.15 \\
(23) Ameri et al. (2011) & 5.55 & 0.09 & 0.06 \\
(24) Baltay et al. (2011) & 6.76 & 0.00 & 0.00 \\
(25) Mayeda and Walter (1996) & 1.93 & 0.27 & 0.51 \\
(26) Garcia-Garcìa et al. (1996) & 7.20 & 0.65 & 0.73 \\
& & & \\
& & &
\end{tabular}

\section{Conclusions}

Since our interest is focused on i) the ddf of the various parameters, ii) the slope of the ddfs and iii) their correlations with the median of the corresponding dataset (considering only the used range), the conclusions concerning the validity of the power laws are somehow disappointing. Indeed, we attempted to correlate the observed scattered slopes in the different ranges of the investigated parameters (stress drop, scalar seismic moment and source radius) to different seismotectonic settings, but we could not find any obvious correlation.

It is also readily seen that the tentative ddf of the different parameters confirm that the parameters with larger values are far less numerous than those with smaller ones and that their ddf is a decreasing but yet uncertain function: the power laws assumed as ddf of physical parameters, as in most fields of science, are a first approximation valid in ranges of the parameters which are sometimes too short to have a reliable physical meaning and should be better investigated.

We have seen that the slopes of the ddfs, often limited to a short range of parameters, are also influenced by the size of the cells of the histogram, and consequently by their number. Accordingly, since the parameters are characterizing the seismotectonic behaviour of a region for assessing its seismic hazard, the classical laws of seismicity, i.e. the power laws and their ddf, should be used with great caution because potentially misleading.

As previously noted, the apparently linear portion of the histograms representing the ddfs of important seismic parameters is often more limited than traditionally assumed. This in turn implies that the laws assumed for the ddf of earthquake's parameters, including the theoretical relations between the source's radius, the stress drop and the displacement (e.g. Eshelby 1957, Caputo 1987), could not be valid over a range sufficiently large to be of practical use, which is not surprising since we all know that for instance any source is far from being a circle and the slip is not regularly distibuted on the rupture area and the sliding surfaces are not flat.

The validity of the classical simplified models of the source is possibly greater when the area of the source is limited which in turn causes the limited interval of validity of the linearity of the ddf. Indeed, small faults have likely a simple geometry, say a circle, due to the possible mechanically homogeneous rock volume and stress field at a small scale. In contrast, when fault dimensions increase, the affected crustal volume similarly increases and the possibility that mechanical heterogeneities occur also increases. As a consequence, the rupture propagation process is strongly influenced and hence for big structures the final geometry of the fault has practically never a simple shape (e.g. a circle) nor the slip distribution has a simple pattern.

Seismology has made progress in the recent decades with the introduction of new parameters with practical and physical significance such as the well-known and widely used corner frequency or the Kagan angle (Kagan 1991), but certainly there is still the need of more, particularly for earthquake prediction and for earthquake engineering. Indeed, when performing seismic hazard assessment analyses using the power-laws statistically inferred from the above discussed parameters, both under- and over-estimates could be introduced in different seismogenic areas. Such errors could therefore alter the risk associated costs either in case of a stronger seismic event (i.e. underestimate) or in the useless attempt of mitigating an overestimated seismic risk.

\section{Acknowledgements}

We are grateful to Jeanne Hardebeck, Adrien Oth and Kazuhiro Somei for kindly providing their datasets.

\section{References}

[1] Abercrombie R (1995) Earthquake source scaling relationships from -1 to $5 \mathrm{ML}$ using seismograms recorded at $2.5-\mathrm{km}$ depth. $\mathrm{J}$. Geophys. $\quad$ Res. 100, 24,015-24,036, http://dx.doi.org/10.1029/95JB02397.

[2] Abercrombie RE \& Rice JR (2005) Can observations of earthquake scaling constrain slip weakening? Geophys. J. Int. 162, 406-424, http://dx.doi.org/10.1111/j.1365-246X.2005.02579.x. 
[3] Aki K (1972) Scaling law of earthquake source time-function. Geophys. J. R. astr. Soc. 31, 3-25.

[4] Allen TI, Gibson G, Brown A \& Cull JP (2004) Depth variation of seismic source scaling relations: implications for earthquake hazard in southeastern Australia. Tectonophys. 390, 5-24, doi: 10.1019/j.tecto.2004.03.018.

[5] Allmann BP \& Shearer PM (2007) Spatial and temporal stress drop variations in small earthquakes near Parkfield, California. J. Geophys. Res. 112, B04305, http://dx.doi.org/10.1029/2006JB004395.

[6] Allmann BP \& Shearer PM (2009) Global variations of stress drop for moderate to large earthquakes. J. Geophys. Res. 114, B01310, http://dx.doi.org/10.1029/2008JB005821.

[7] Ameri G, Oth A, Pilz M, Bindi D, Parolai S, Luzi L, Mucciarelli M \& Cultrera G (2011) Separation of source and site effects by generalized inversion technique using the aftershock recordings of the 2009 L'Aquila earthquake. Bull Earthquake Eng. 9, 717-739, http://dx.doi.org/10.1007/s10518-011-9248-4.

[8] Andrews DJ (1986) Objective determination of source parameters and similarity of earthquakes of different size. In Das S, Boatwright J \& Scholz CH (Eds.), Earthquake Source Mechanics, 259-267, American Geophysical Union, Washington DC, http://dx.doi.org/10.1029/GM037p0259.

[9] Asano K \& Iwata T (2011) Characterization of stress drops on asperities estimated from the heterogeneous kinematic slip model for strong motion prediction for inland crustal earthquakes in Japan. Pure Appl. Geophys. 168, 105-116, http://dx.doi.org/10.1007/s00024-010-0116-y.

[10] Baltay AS, Ide S, Prieto G \& Beroza GC (2011) Variability in earthquake stress drop and apparent stress. Geophys. Res. Lett. 38, L06303, http://dx.doi.org/10.1029/2011GL046698.

[11] Baltay AS, Beroza GC \& Ide S (2014) Radiated energy of great earthquakes from teleseismic empirical Green's function deconvolution. Pure Appl. Geophys. 171, 2841-2862, http://dx.doi.org/10.1007/s00024-014-0804-0.

[12] Baltay AS, Hanks TC \& Beroza GC (2013) Stable stress-drop measurements and their variability: implications for ground-motion prediction. Bull. Seismol. Soc. Am. 103(1), 211-222, http://dx.doi.org/10.1785/0120120161.

[13] Bilek SL, Lay T \& Ruff LJ (2004) Radiated seismic energy and earthquake source duration variations from teleseismic source time functions for shallow subduction zone thrust earthquakes. J. Geophys. Res. 109, B09308, http://dx.doi.org/10.1029/2004JB003039.

[14] Boore DM (1983) Stochastic simulation of jhigh-frequency ground motions based on seismological models of the radiated spectra. Bull. Seismol. Soc. Am. 73(6), 1865-1894

[15] Bora DK, Baruah S, Biswas R \& Gogoi NK (2013) Estimation of source parameters of local Earthquakes originated in ShillongMikir Plateau and its adjoining region of Northeastern India. Bull Seismol. Soc. Am. 103(1), 437-446, http://dx.doi.org/10.1785/0120120095.

[16] Calderoni G, Rovelli A, Cultrera G, Azzara RM \& Di Giulio G (2005) Assessment of ground motion in Palermo, Italy, during the 6 September $2002 \mathrm{Mw} 5.9$ earthquake using source scaling law. Bull. Seismol. Soc. Am. 95(6), 2342-2363, http://dx.doi.org/10.1785/0120050063.

[17] Calderoni G Rovelli A \& Singh SK (2013) Stress drop and source scaling of the 2009 April L'Aquila earthquakes. Geophys. J. Int 192, 260-274, http://dx.doi.org/10.1093/gji/ggs011.

[18] Caputo M (1976) Properties of earthquake statistics. Ann matematica pura e applicata, Ser. IV, CXI, 186-193. http://dx.doi.org/10.1007/bf02411818.

[19] Caputo M (1981) Earthquake-induced ground accelerations. Nature 51(5810), 51-53, http://dx.doi.org/10.1038/291051a0.

[20] Caputo M (1982) On the reddening of the spetra of Earthquake parameters, Earthquake prediction research 1, 173-181,

[21] Caputo M (1987) the interpretaion of the b and b0 values and its implications on the regional deformation of the crust. Geophys. J. R. astr. Soc. 990, 551- 573

[22] Caputo M (1998) the density distribution of the fractured asperities on the surfaces of a fault. Phys. Earth Planet. Int. 109, 9-23. http://dx.doi.org/10.1016/S0031-9201(98)00109-5.

[23] Caputo M, Gasperini P, Keilis-Borok V, Marcelli L \& Rotwain I (1977) Earthquake's swarms as forerunners of strong earthquakes in Italy, Ann. Geophys. 30(3-4), 269-283.

[24] Cocco M \& Rovelli A (1989) Evidence for the variation of stress drop between normal and thrust faulting earthquakes. J. Geophys. Res. 94, 9399-9416. http://dx.doi.org/10.1029/JB094iB07p09399.

[25] Cotton F, Archuleta R \& Causse M (2013) what is sigma of the stress drop? Seismol. Res. Letts. 84(1) http://dx.doi.org/10.1785/0220120087.
[26] Escudero CR \& Doser DI (2012) Relative source-time function studies and stress drop of earthquakes in Southeastern AlaskaNorthwestern Canada. Bull. Seismol. Soc. Am. G102G (4), 1820 1828, http://dx.doi.org/10.1785/0120110252.

[27] Eshelby JD (1957) the determination of the elastic field of an ellipsoidal inclusion and related problems. Proc. R. Soc London, a 241, 376-396. http://dx.doi.org/10.1098/rspa.1957.0133.

[28] Gabrielov A, Keilis-Borok V, Sinai Ya \& Zaliapin I (2008) Statistical Properties of the Cluster Dynamics of the Systems of Statistical Mechanics. In Boltzmann's Legacy, ESI Lectures in Mathematics and Physics, EMS Publishing House, 203-216. http://dx.doi.org/10.4171/057-1/13.

[29] Garcìa-Garcìa JM, Vidal F, Romacho MD, Martìn-Marfil JM, Posadas a \& Luzòn F (1996) Seismic source parameters for microearthquakes of the Granada basin (southern Spain). Tectonophys. 261, 51-66. http://dx.doi.org/10.1016/0040-1951(96)00056-x.

[30] Giampiccolo E, D’Amico S, Patanè D \& Gresta S (2007) Attenuation and Source Parameters of Shallow Microearthquakes at Mt. Etna Volcano, Italy. Bull. Seismol. Soc. Am. 97(1B), pp. 184-197, http://dx.doi.org/10.1785/0120050252.

[31] Giampiccolo E, Musumeci C, Falà F \& Gresta S (2008) Seismological investigations in the Gioa Tauro Basin (southern Calabria, Italy). Ann. Geophys. 51(5/6), 184-197.

[32] Gibowicz SJ, Young RP, Talebi S \& Rawlence DJ (1991) Source parameters of seismic events at the underground research laboratory in Manitoba, Canada: scaling relations for events with moment magnitude smaller than -2. Bull. Seismol. Soc. Am. 81(4), $1157-$ 1182.

[33] Hanks TC (1977) Earthquake stress drops, ambient tectonic stresses and stresses that drive plate motions. Pure Appl. Geophys. 115 , 441-458. http://dx.doi.org/10.1007/BF01637120.

[34] Hanks TC \& Wyss M (1972) the use of body-wave spectra in the determination of seismic-source parameters. Bull. Seismol. Soc. Am. 62(2) 561-589.

[35] Hardebeck JL \& Hauksson E (1997) Static stress drop in the 1994 Northridge, California, aftershock sequence. Bull. Seismol. Soc. Am. 87(6), 1495-1501.

[36] Hauksson E. (2015) Average stress drops of Southern California earthquakes in the context of crustal geophysics: implications for fault zone healing. Pure Appl. Geophys. 172, 1359-1370, http://dx.doi.org/10.1007/s00024-014-0934-4.

[37] Hauksson E, Stock J, Bilham R, Boese M, Chen X, Fielding EJ, Galetzka J, Hudnut KW, Hutton K, Jones LM, Kanamori H, Shearer PM, Steidl J, Treiman J, Wei S \& Yang W (2013) Report on the August 2012 Brawley earthquake swarm in Imperial Valley, Southern California. Seismol. Res. Letts. 84(2), 177-189, http://dx.doi.org/10.1785/0220120169.

[38] Hough SE \& Dreger DS (1995) Source parameters of the 23 April 1992 M 6.1 Joshua Tree, California, earthquake and its aftershocks: empirical Green's function analysis of GEOS and TERRAscope data. Bull. Seismol. Soc. Am. 85(6), 1576-1590.

[39] Ide S \& Beroza GC. (2001) Does apparent stress vary with earthquake size? Geophys. Res. Lett. 28(17), 3349-3352. http://dx.doi.org/10.1029/2001GL013106.

[40] Ide S, Beroza GC, Prejean SG \& Ellsworth WL (2003) apparent break in earthquake scaling due to path and site effects on deep borehole recordings. J. Geophys. Res. 108(B5), 2271, http://dx.doi.org/10.1029/2001JB001617.

[41] Jin A, Moya CA \& Ando M (2000) Simultaneous determination of site responses and source parameters of small earthquakes along the Atotsugawa Fault Zone, Central Japan. Bull. Seismol. Soc. Am. 90(6), 1430-1445. http://dx.doi.org/10.1785/0119990140.

[42] Jost ML, Büsselberg T, Jost Ö \& Harjes H-P (1998) Source parameters of injection-induced microearthquakes at $9 \mathrm{~km}$ depth at the KTB deep drilling site, Germany. Bull. Seismol. Soc. Am. 88(3), 815-832.

[43] Kagan YT (1991) 3-D rotation of double-couple earthquake sources, Geophys. J. Int. 106, 709-716. http://dx.doi.org/10.1111/j.1365246X.1991.tb06343.x.

[44] Kanamori H \& Anderson DL (1975) Theoretical basis of some empirical relations in seismology. Bull. Seismol. Soc. Am. 65(5), 1073-1095.

[45] Kanamori H \& Rivera L (2004) Static and dynamic scaling relations for earthquakes and their implications for rupture speed and stress drop. Bull. Seismol. Soc. Am. 94(1), 314-319. http://dx.doi.org/10.1785/0120030159.

[46] Kato N (2009) A possible explanation for difference in stress drop between intraplate and interplate earthquakes. Geophys. Res. Lett. 36, L23311, http://dx.doi.org/10.1029/2009GL040985. 
[47] Knopoff L (1958) Energy release in earthquakes. Geophys. J. R. astr. Soc. 1(1), 44-52, doi: 10.1111/j.1365-246X.1958.Cb00033.x.

[48] Kumar N, Yadav DK, Mondal SK \& Roy PNS (2013) Stress drop and its relations to tectonic and structural elements for the meizoseismal region of great 1905 Kangra earthquake of the NW Himalaya. Nat. Hazards 69, 2021-2038, doi: 10.1007/s11069-013-0793-9.

[49] Kwiatek G, Plenkers K, Dresen G \& JAGUARS Research Group (2011) Source parameters of picoseismicity recorded at Mponeng deep gold mine, South Africa: implications for scaling relations. Bull. Seismol. Soc. Am. 101(6), 2592-2608, http://dx.doi.org/10.1785/0120110094.

[50] Lindley GT (1994) Source parameters of the 23 April 1992 Joshua tree, California, earthquake, ita largest foreshock, and aftershocks. Bull. Seismol. Soc. Am. 84, 1051-1057.

[51] Malagnini L, Mayeda K, Nielsen S, Yoo S-H, Munafò I, Rawles C \& Boschi E (2014a) Scaling transition in earthquake sources: a possible link between seismic and laboratory measurements. Pure Appl. Geophys. 171, 2685-2707, http://dx.doi.org/10.1007/s00024-0130749-8.

[52] Malagnini L, Munafò I, Cocco M, Nielsen S, Mayeda K \& Boschi E (2014b) Gradual fault weakening with seismic slip: inferences from the seismic sequences of L'Aquila, 2009, and Northridge, 1994. Pure Appl. Geophys. 171, 2709-2730, http://dx.doi.org/10.1007/s00024-013-0752-0.

[53] Mayeda K. \& Walter W.R. (1996) Moment, energy, stress drop, and source spectra of western United States earthquakes from regional coda envelopes. J. Geophys. Res. 101(B5), 11,195-11,208. http://dx.doi.org/10.1029/96JB00112.

[54] Mayeda K, Gök R, Walter WR \& Hofstetter A (2005) Evidence for non-constant energy/moment scaling from coda-derived source spectra. Geophys. Res. Lett. 32, L10306, http://dx.doi.org/10.1029/2005GL022405.

[55] McGarr A (1984) Scaling of ground motion parameters, state of stress, and focal depth. J. Geophys. Res. 89, B8, 6969-6979, http://dx.doi.org/10.1029/jb089ib08p06969.

[56] McGarr A (1999) on relating apparent stress to the stress causing earthquake fault slip. J. Geophys. Res. 104(B2), 3003-3011. http://dx.doi.org/10.1029/1998JB900083.

[57] Mori J, Abercrombie RE \& Kanamori H (2003) Stress drop and radiated energies of aftershocks of the 1994 Northridge, California, earthquake. J. Geophys. Res. 1089(B11), 2545 , http://dx.doi.org/10.1029/2001JB000474.

[58] Oth A (2013) on the characteristics of earthquake stress release variations in Japan. Earth Planet. Sc. Letts. 377-378, 132-141, http://dx.doi.org/10.1016/j.epsl.2013.06.037.

[59] Oth A \& Kaiser AE (2014) Stress release and source scaling of the 2010-2011 Canterbury, New Zealand earthquake sequence from spectral inversion of ground motion data. Pure Appl. Geophys. 171, 2767-2782, http://dx.doi.org/10.1007/s00024-013-0751-1

[60] Patanè D, Ferrucci F, Giampiccolo E \& Scaramuzzino L (1997) Source scaling of microearthquakes at Mt. Etna volcano and in the Calabrian Arc (southern Italy). Geophys. Res. Lett. 24(15), 18791882. http://dx.doi.org/10.1029/97GL01745.

[61] Perez-Campos X \& Beroza GC (2001) an apparent mechanism dependence of radiate seismic energy. J. Geophys. Res. 106 (B6), 11,127-11,136. http://dx.doi.org/10.1029/2000JB900455.

[62] Prejean SG \& Ellsworth WL (2001) Observations of earthquake source parameters at $2 \mathrm{~km}$ depth in the Long Valley Caldera, Eastern California. Bull. Seismol. Soc. Am. 91(2), 165-177. http://dx.doi.org/10.1785/0120000079.

[63] Rovelli A \& Calderoni G (2014) Stress drop of the 1997-1998 Colfiorito, Central Italy earthquake: hints for a common behaviour of normal faults in the Apennines. Pure Appl. Geophys. 171, 27312746, http://dx.doi.org/10.1007/s00024-014-0856-1.

[64] Ruff LJ (1999) Dynamic stress drop of recent earthquakes: variations within subduction zones. Pure Appl. Geophys. 154, 309-431. http://dx.doi.org/10.1007/978-3-0348-8679-6_2_.

[65] Senatorskt P (2012) Effect of seismic moment-area scaling on apparent stress-seismic moment relationship. Pyhs. Earth Planet. Int. 196-197, 14-22, http://dx.doi.org/10.1016/j.pepi.2012.02.001.

[66] Shearer PM, Prieto GA \& Hauksson E (2006) Comprehensive analysis of earthquake source spectra in southern California. J. Geophys Res. 111, B06303, http://dx.doi.org/10.1029/2005JB003979.

[67] Somei K, Asano K, Iwata T \& Miyakoshi K (2014) Source scaling of inland crustal earthquake sequences in Japan using the S-wave coda spectral ratio method. Pure Appl. Geophys. 171, 2747-2766, http://dx.doi.org/10.1007/s00024-014-0774-2.

[68] Stork AL \& Ito H (2004) Source parameter scaling for small earthquakes observed at the Western Nagano 800-m-deep borehole,
Central Japan. Bull. Seismol. Soc. Am. 94(5), 1781-1794. http://dx.doi.org/10.1785/012002214.

[69] Tomic J, Abercrombie RE \& do Nascimento AF (2009) Source parameters and rupture velocity of small $\mathrm{M} \leq 2: 1$ reservoir induced earthquakes. Geophys. J. Int. 179, 1013-1023, http://dx.doi.org/10.1111/j.1365-246X.2009.04233.x.

[70] Tusa G, Brancato A \& Gresta S (2006a) Source parameters of microearthquakes in Southeastern Sicily, Italy. Bull. Seismol. Soc. Am. 96(3), 968-983, http://dx.doi.org/10.1785/0120050071.

[71] Tusa G, Brancato A, Gresta S \& Malone SD (2006b) Source parameters of microearthquakes at Mount St. Helens (USA). Geophys. J. Int., 166, 1193-1223 http://dx.doi.org/10.1111/j.1365246X.2006.03025.x.

[72] Wang L, Zöller G \& Hainzl S (2015) Joiont determination of slip and stress drop in a Bayesian inversion approach: a case study for the 2010 M8.8 Maule earthquake. Pure Appl. Geophys. 172, 375388, http://dx.doi.org/10.1007/s00024-014-0868-x.

[73] Yamada T, Mori JJ, Ide S, Abercrombie RE, Kawakata H, Nakatani M, lio Y. \& Ogasawara H (2007) Stress drops and radiated seismic energies of microearthquakes in a South African gold mine. J. Geophys. Res. 112, B03305, http://dx.doi.org/10.1029/2006JB004553.

[74] Zaliapin I, Gabrielov A, Keilis-Borok V \& Wong H (2008) Clustering analysis of seismicity and aftershock identification. Phys. Rev. Letters 101 , 018501 , 